\title{
A CASA DE JOANA DARK: DRAMA E MONTAGEM*
}

John Cowart Dawsey

Joana D'Arc...! Aquela era mulher de verdade, uma santa!

(Palavras de Diolíndia, após assistir a um filme na televisão, 21/01/84)

\section{Circuitos}

Neste ensaio pretendo dizer algo sobre imagens de mães e mulheres, tais como elas lampejam no Jardim das Flores, o "buraco dos capetas". Para este fim, vou revisitar anotações feitas em cadernos de campo nos anos 1980. Nessa época, o Jardim das Flores era uma ravina, ou pequeno abismo que, em testemunho de poderosas forças de erosões geológicas e sociais, irrompia na periferia de Piracicaba, uma cidade do interior paulista. Em suas encostas alojava-se uma centena de barracos. Ali se apresentava uma imagem do Brasil: havia gente dos sertões do Norte, Nordeste, CentroOeste, Sul e Sudeste e também gente de substratos piracicabanos oriunda do antigo bairro do Risca-Faca, de cujas cinzas de mato queimado o Jardim das Flores surgiu.

O percurso de muitas dessas pessoas evocava um rito de passagem insólito: a passagem para um estado de passagem - o estranhamento de quem se via virando "boia-fria" (Dawsey 1999, 2005). O pasmo cotidiano. Em meados dos anos de 1970, grande parte do interior paulista transformara-se em canavial. Com a "crise do petróleo" e o esgotamento do "milagre econômico" brasileiro, foram criados os grandes projetos de desenvolvimento Proálcool e Planalçúcar. Nesse cenário, irromperam os "boias-frias" cortadores de cana. Multidões de pessoas saíam dos sertões para residir em barracões de usinas e barracos em periferias de cidades onde circulavam os caminhões e os ônibus de "boias-frias". Nos canaviais produziam as fontes de energia renovável que alimentavam a indústria automobilística. Em meio a um clima de embriaguez de uma nação movida por sonhos de progresso, os "boias-frias" tomavam o lugar dos sheiks do petróleo. 
Em Piracicaba, conforme relatos de pessoas do "buraco dos capetas", antes de virarem "boias-frias", elas construíram um parque industrial. Ergueram a Caterpillar, uma fábrica de tratores e máquinas que, no campo, tomavam os lugares de quem vinha para a cidade. Um detalhe: entre as máquinas que ali seriam produzidas, as colheitadeiras de cana iriam permanecer - como até hoje, em grande parte, permanecem - nas vitrines de lojas e de usinas. Depois de haverem construído a Caterpillar, seguem os relatos, as pessoas "caíram no buraco" - o "buraco dos capetas". Também "caíram na cana", virando "boias-frias".

Nesse lugar fui acolhido por um casal do norte de Minas Gerais: uma mulher que vou chamar de Anaoj e seu marido, Mister Zé. ${ }^{1}$ Tive o privilégio, em 1983, de fazer parte do circuito de suas relações. ${ }^{2}$ Fios elétricos de cores diferentes, improvisados pelos moradores, emendando-se uns nos outros, iluminavam o Jardim das Flores. Atravessando o espaço em múltiplas direções, eles forneciam pistas para se detectar a configuração de redes sociais.

A trajetória labiríntica percorrida pelos fios do barraco de Anaoj revela um sistema de energia que envolve vários barracos. Trazendo a força que vem da rua, os fios entram no barraco de Aparecida e Gabriel (primeira filha e genro de Anaoj). Dali seguem para o barraco de Margarida e Manuel (cunhada e irmão de Gabriel). Suspensos por uma vara de bambu, os fios sobem ladeira. Passam pelo cômodo de Maria e Zé do Mar (segunda filha e genro de Anaoj). Penetram o barraco de Anaoj e Mister Zé, onde também moram os dois filhos mais novos do casal: Daniel e Moisés. Logo então, os fios entram no cômodo do pesquisador - eu mesmo - a quem, despertando risos, Anaoj às vezes se refere como o seu filho branco: "João Branco" ou "João de Anaoj". Saindo desse cômodo, os fios se conectam com a lâmpada em frente ao barraco de Anaoj e Mister Zé. Dali, com a ajuda de uma segunda vara de bambu, os fios cruzam por cima de uma valeta até alcançarem, ao lado do saravá, o barraco de Jasmim e Jeremias (nora e primeiro filho homem de Anaoj). Dos seis filhos vivos de Anaoj, apenas Adão, o segundo na ordem de idade dos filhos homens, mora em outro bairro (19/07/83).

A imagem é propícia. Parentes e vizinhos, unidos por redes de energia, transmitem força uns para os outros. Mas não deixam de ocorrer curtos-circuitos. O Jardim das Flores se ilumina especialmente através de lampejos, nas inervações corporais resultantes de choques cotidianos, e nas relações eletrizantes envolvendo mulheres e homens. As redes estão carregadas de tensões. 
A seguir me arrisco a discutir algumas de suas imagens mais luminosas, produzidas por espelhos de mães e mulheres do "buraco dos capetas". Nos cadernos de campo, elas fulguram em três conjuntos de relações: Anaoj e seus filhos, Maria e Zé do Mar, e Anaoj e Mister Zé.

\section{Uma estética de Nossa Senhora}

$\mathrm{Na}$ literatura antropológica referente a populações do baixo corpo social, imagens de mães se associam aos poderes de mediação. Talvez mais do que em qualquer outro estrato o corpo da mãe vira a sua metonímia. Em meio ao caos que frequentemente acompanha os deslocamentos errantes de filhos, companheiros e esposos, as mães e mulheres tecem os fios que sustentam a própria vida. Tal como se costuram colchas de retalhos das sobras e dos recortes de diferentes cores e texturas, emergem arranjos de vida nesses substratos. Tal como se juntam na obra de um bricoleur os materiais sensíveis do seu mundo, reúnem-se em torno de mães e mulheres os elementos que animam as redes de parentesco e vizinhança. Assim se fundam teias de reciprocidade. E se infunde um pequeno terror: o medo de ver-se sem as próprias teias. Trata-se de redes carregadas de tensões. Remendadas, ruídas e tecidas com rudes materiais, as redes que protegem também precisam ser protegidas. Mães e mulheres reparam as redes que elas próprias tecem.

Em sociedades católicas uma ação mediadora se transfigura no espelho mágico de Nossa Senhora. ${ }^{3}$ As redes se ampliam. Tornam-se poderosas e surpreendentes. Lugares ermos onde lampejam imagens de virgens mães de Deus transformam-se em pontos luminosos de peregrinações e romarias. Relações de gênero também se tecem no plano do sagrado.

Neste ensaio, tenho interesse em explorar a especificidade de estéticas dramáticas para entender o modo como, em gestos e inervações corporais, se configuram imagens de Nossa Senhora e de mães e mulheres no Jardim das Flores. Considerando-se a força da ação mediadora de tais personagens talvez seja possível se falar, nos termos de Victor Turner, de uma estética do drama social. Inspirando-se no pensamento teatral, Turner (1982:10; 1996:91-94) encontra nos dramas sociais uma estética da tragédia grega, e um modelo que se desdobra em quatro momentos: 1. ruptura, 2. crise e intensificação da crise, 3. ação reparadora, e 4. desfecho. Na literatura antropológica referente às classes ou às camadas inferiores da sociedade, momentos de "ruptura" geralmente se associam ao gênero masculino, e "ações reparadoras" ao gênero feminino. 
Aqui, porém, pretendo investigar os alcances de outra estética para se pensarem as imagens de mães e mulheres no Jardim das Flores, e de sua ação mediadora: a da montagem. Tal estética - que se associa ao cinema de Sergei Eisenstein (1990a, 1990b) e às vanguardas artísticas do início do século 20 - também irrompe em momentos expressivos do Jardim das Flores. Um dos registros de cadernos de campo, capaz de fazer estremecer a própria noção de sincretismo, é particularmente revelador. No final do circuito elétrico formado por barracos do grupo de parentesco e vizinhança de Anaoj e Mister Zé, em um dos seus pontos mais frágeis, uma missa transforma-se em montagem:

Naquela mesma noite Padre Ângelo rezou missa no barraco de Jasmim e Jeremias. A ideia da missa surgira após uma série de acontecimentos explosivos. Além de ver-se em brigas tempestuosas com a Jasmim, Jeremias envolvia-se em brigas de bar. Invocando as forças do alto, Anaoj procurava conter a braveza do seu filho.

Às 19h, fazendo uso de um alto-falante, o ajudante do padre lança um convite: "Estamos aqui na casa de Jeremias, um rapaz pobre como todos nós. 'Feliz o pobre!', disse Jesus. Mas falamos do pobre de espírito, o que não briga com os outros. O que perdoa o seu inimigo, esse é pobre. Venham participar da santa missa!"

Às $19 \mathrm{~h} 10$ ouve-se um estrondo, um tiro de garrucha! O tiro vem do vizinho de Jeremias, do barraco do "Saravá". O "Professor Pardal", um inventor de garruchas e de livros de dar choque, está "testando" uma de suas invenções. Às 19h30, o padre começa a rezar missa. Às 20h20, um segundo estrondo. Às 20h25, após uma leitura bíblica, ouve-se um terceiro tiro. O padre faz um sermão sobre a importância de "sermos bons para que Deus mande coisas boas". Às 20h50, após a oração do "Pai Nosso", o barraco do "Saravá" irrompe em sons do atabaque. Tentando dirigir uma liturgia a respeito do "Cordeiro de Deus que curais o pecado do mundo", o padre reclama: "Quanto barulho! Quanto barulho!".

Da pequena congregação surge um cântico sobre o amor ao próximo. A batida do atabaque se intensifica. Padre Ângelo incentiva os cânticos. Ele volta a falar. O seu português dispara, tornando-se ininteligível, e parecendo haver se transfigurado em algum dialeto italiano. Finalmente, o atabaque e o padre chegam ao fim. Padre Ângelo termina com um cântico de louvor a Nossa Senhora Aparecida (27/07/83).

Essa montagem carregada de tensões, de uma missa piedosa pontuada por tiros, e de leituras bíblicas e cânticos de louvor acompanhados pela 
batida alucinante de um atabaque, é uma expressão do Jardim das Flores e das relações que tomam vida em circuitos de família e vizinhança. Se, por um lado, com vozes brandas, o padre e seu ajudante invocavam a presença serena e humilde da mãe de Deus, recobrindo o barraco de Jasmim e Jeremias com a aura de Nossa Senhora, por outro, os tiros do Professor Pardal e as batidas de atabaque do barraco vizinho faziam estremecer o Jardim das Flores, num clima explosivo quase em estado de frenesi.

Eisenstein (1990a:41) escreve: "O que, então, caracteriza a montagem e, consequentemente, sua célula - o plano? A colisão. O conflito de duas peças em si. O conflito. A colisão". Tal concepção de montagem teve influência marcante nos escritos de Walter Benjamin e no teatro de Bertolt Brecht. $\mathrm{Na}$ antropologia, observa-se o seu impacto particularmente nos escritos de Michael Taussig, com destaque para o livro Xamanismo, colonialismo e o homem selvagem (Taussig 1986). As ideias de George Marcus quanto à relevância de procedimentos relacionados ao cinema em face dos novos desafios da descrição etnográfica também chamam a atenção. Creio, porém, que sua concepção de montagem — voltada para captar "existências paralelas através de justaposições da vida cotidiana em diferentes locais" (Marcus 1994:51) — aproxima-se mais dos filmes de David Wark Griffith e da história originária do cinema norte-americano do que dos experimentos de Eisenstein. Quanto a essas diferentes concepções, o cineasta russo comenta: "Ao paralelismo e à alternância de primeiros planos dos Estados Unidos oferecemos o contraste de uni-los em fusão" (Eisenstein 1990a:202). A partir da fusão de dois fatores em conflito cria-se uma imagem ou montagem carregada de tensões.

\section{Subterrâneos dos símbolos}

Num artigo sobre Hidalgo e a revolução mexicana, Victor Turner (1974:105) ressalta que Nossa Senhora de Guadalupe, um dos símbolos poderosos de uma nacionalidade emergente, é a sucessora de Tonantzin, a mãe dos deuses na cosmologia asteca, cujo culto, anteriormente celebrado no mesmo lugar agora dedicado ao culto de Nossa Senhora de Guadalupe, havia sido eliminado pelos espanhóis. Sugere-se uma questão: haveria no registro de uma missa pontuada por tiros de garrucha do Professor Pardal os indícios de uma Nossa Senhora que também se revela como outra - de forma explosiva? Uma observação: sabe-se que a imagem da padroeira do Brasil, Nossa Senhora Aparecida, é fendida. Na audição desse registro ouviríamos os estrondos de uma "história noturna", irrompendo dos fundos de uma memória involuntária, ou do inconsciente sonoro de um baixo corpo social? ${ }^{4}$ Brotariam 
tais ruídos das fendas de uma cisão social? Seriam eles os barulhos de uma revoada, tal como num teatro de Antonin Artaud (1987), onde se agitam as sombras de uma nação?

Edmund Leach (1983:129) observa que os cultos à Virgem ganham força em sociedades patriarcais altamente hierarquizadas, tais como a do Brasil colonial, nas quais "senhores jamais se casam com pessoas de classes inferiores, mas [...] graciosamente se dignam a tomar escravas como concubinas e a elevar seus filhos à altura da elite". Nas inervações corporais de mães e mulheres do Jardim das Flores seria possível detectar a fricção produzida pelo encontro, em uma montagem carregada de tensões, de duas ou três linhagens sobrepostas - envolvendo as filhas e devotas de Nossa Senhora, de um lado, e as filhas ou netas e bisnetas de "negas de senzala" e "índias laçadas no mato", de outro?

\section{Pureza e perigo}

Os tiros que afloram como as flores do mal de uma garrucha do saravá poderiam evocar a imagem de uma espécie de mãe primordial? Ou a experiência do abjeto? "O feminino é tonitruante e terrível", escreve Artaud (1987:169). Pureza e perigo. A junção das imagens evoca o título de um livro de Mary Douglas (1976). E, em estado de fricção, dois escritos de Júlia Kristeva (1980; 2002a): Pouvoirs de l'horreur e "Stabat Mater".

Em Pouvoirs de l'horreur, Kristeva interpreta a experiência primordial do feminino: lugar hediondo, sujo, ambíguo, e liminar. Corpo de mãe. Fecundante e estranhamente familiar. Nem eu, nem outro, nem nada. O abjeto não se apresenta simplesmente como um objeto, contrapondo-se ao eu. No abjeto o próprio eu se decompõe. Anterior à ordem simbólica, o abjeto coloca toda ordem em estado de risco. Sob a luz negra da abjeção, a mãe-mulher se revela. Perigosa!

Em "Stabat Mater", Kristeva discute o lugar da Virgem Nossa Senhora na constituição do universo social e simbólico do Cristianismo. Afinidades com o trabalho de Mary Douglas também aqui são notáveis. A formação de ordens simbólicas envolve processos de purificação. Na atribuição de virgindade à Maria, mãe de Cristo - que surge, diz Kristeva (2002a:312), de um "erro de tradução" - levanta-se uma suspeita: suas relações de afinidade com homens poderosos. Dramas de tradução? E de traição? Purificada do "pecado", Maria torna-se mãe de Deus. Vira rainha. No imaginário das cortes medievais, e dos poderes que se associam às senhoras da nobreza feudal, ela vira Nossa Senhora. Um detalhe: com a transformação de Maria 
em Virgem, o corpo materno se reduz ao silêncio (Kristeva 2002b:296-297). A Virgem se cala.

Às leitoras e aos leitores que se propuserem a fazer uma audição dessa Senhora, sugiro cautela. Pois talvez se deparem com um tiro de garrucha.

Também peço atenção. A discussão sobre a imagem de Nossa Senhora não deixa de se apresentar como um desvio motivado por um registro etnográfico de uma missa-saravá, lido a partir de uma estética da montagem e sob a luz negra do pensamento de Kristeva e do teatro de Artaud. Assim, acredito, se obtém o deslocamento necessário para explorar as inervações corporais das mulheres do Jardim das Flores. Eis o foco deste ensaio: as relações dessas mulheres - particularmente as da Casa de Anaoj — com seus filhos e companheiros. E, com outros homens que povoam seu universo social.

Um tema se enuncia: a imagem de mãe e mulher. Observa-se o procedimento de Eisenstein (1990b:18):

A representação A e a representação B devem ser selecionadas entre todos os aspectos possíveis do tema em desenvolvimento, devem ser procuradas de tal modo que sua justaposição - isto é, a justaposição desses próprios elementos e não de outros, alternativos - suscite na percepção e nos sentimentos do espectador a mais completa imagem do próprio tema.

$\mathrm{Na}$ releitura de registros de cadernos de campo que proponho a seguir, duas representações foram selecionadas. A representação A fulgura sob o signo da Virgem, de uma imagem de Pietá, ou "mulher sofrida". Frequentemente ela aparece como vítima da violência de "homens errantes ou marginais" - ou seja, conforme se evidencia nos registros, de seus próprios companheiros e filhos "pecadores". Por vezes, essa "mãe e mulher sofrida" também evoca afinidades com homens poderosos e seus meios de comunicação, constituindo-se em uma das forças vitais de ordens sociais e simbólicas.

A representação B irrompe sob o signo de uma outra, da mãe perigosa e da mulher "doida de raiva". Trata-se de uma imagem de mulher furiosa, capaz de matar - e sem medo de enfrentar "os homens".

No experimento que aqui se propõe as duas representações se alternam e se sobrepõem em velocidade. Seria tentador, em alguns casos, fazer uma leitura do material tendo em vista três momentos: representação A, representação $\mathrm{B}$, e fusão de ambas as representações. Desse modo, poderíamos propor um modelo alternativo ao do drama social, de Victor Turner. O exercício exige cuidado. Acredito que todo modelo corre riscos de se transformar, como 
disse Geertz (1983:28) em relação ao modelo de Turner, em "uma fórmula para todas as estações" (a form for all seasons). Neste ensaio, talvez o risco maior seja o de suprimir a natureza explosiva do material.

O comentário de Eisenstein (1990a:42) é propício: “Se a montagem deve ser comparada a alguma coisa, então uma legião de trechos de montagem, de planos, deveria ser comparada à série de explosões de um motor de combustão interna". E, ainda outro: "Um personagem [...] para produzir uma impressão verdadeiramente viva, deve ser construído diante do espectador, durante o curso da ação, e não apresentado como uma figura mecânica com características determinadas a priori" (Eisenstein 1990b:21). Embora duas representações tenham sido selecionadas, é preciso estar atento aos movimentos surpreendentes dos personagens. E aos lampejos, ou instantes fugidios, quando representações opostas se fundem numa única imagem, ou montagem carregada de tensões.

\section{Reino dos mortos}

O efeito de montagem produzido por um (des)encontro entre a missa e o saravá ilumina as relações que se tecem no Jardim das Flores. Entre as personagens que aqui fulguram, relampeiam imagens de mães e mulheres. O que dizer sobre elas?

Um aviso: a casa de Anaoj não existe mais. Ao se entrar no reino dos mortos, revisitando os lugares de um tempo que já passou, sente-se no corpo um leve arrepio. A quem pedir passagem? Também surge, à distância, como quem olha as coisas de um lugar privilegiado, bem acima do "buraco dos capetas", uma tentação: a de se transformar em heróis as personagens de velhos e desbotados cadernos de campo. Talvez, de fato, no ensaio que aqui se anuncia, esse cair em tentação seja difícil de evitar. Mas não há heróis no Jardim das Flores. Há contradições. De acordo com Bertolt Brecht, "só tem vida o que é cheio de contradições" (apud Bornheim 1992:272). Talvez, de fato, seja preciso desmontar "heróis" e "heroínas" — até mesmo os da grandeza de Anaoj e Mister Zé - para que as personagens tenham vida.

Nem por isso uma espécie de heroísmo cotidiano - ao gosto de Brecht - deixa de caracterizar algumas das personagens do Jardim das Flores. Os pequenos lamentos e súplicas de Anaoj às vezes eram dessa natureza: "Ai Deus, me dá força de banhar!" (07/06/83). Caso se montasse uma peça teatral a partir de personagens do Jardim das Flores, um dos diálogos de Mãe Coragem, envolvendo um capelão e a própria Coragem, seria sugestivo: 
Capelão - O jeito de a senhora tratar dos seus negócios e ir sempre em frente é uma coisa que eu admiro muito: entendo bem por que lhe deram o apelido de Coragem.

Mãe Coragem — Quem é pobre precisa ter coragem, senão está perdido. Até para sair da cama cedo, e aguentar o rojão! Para lavrar um alqueire de terra, em plena guerra! E ainda pôr mais crianças no mundo é prova de coragem: porque não há nenhuma perspectiva. Os pobres têm de ser carrascos uns dos outros, e se matarem reciprocamente, para depois se olharem cara a cara: então precisam ter muita coragem. Suportar um imperador e um papa é sinal de uma coragem tremenda, e isso custa a própria vida deles! Senta-se, tira do bolso um pequeno cachimbo, e começa a fumar. O senhor bem que podia rachar um pouquinho de lenha... (Brecht 1991:230).

Como um intruso conhecido que novamente pede passagem à Casa de Anaoj — num momento em que este se afunda no reino das sombras — convido leitoras e leitores a uma releitura de trechos de cadernos de campo. O material se organiza em três seções principais: 1. Anaoj e seus filhos, 2. Maria e Zé do Mar (filha e genro de Anaoj e Mister Zé), e 3. Anaoj e Mister Zé. A primeira seção subdivide-se em três: a) Anaoj e Jeremias, b) Anaoj e Daniel, e c) Anaoj e Moisés. No intervalo entre as duas últimas subdivisões, duas digressões se apresentam: uma sobre "a revolta de Anaoj com o papel de mãe e mulher", e outra sobre "o caso de Zé Galinha".

\section{Anaoj e seus filhos}

Anaoj e Jeremias. Dos filhos de Anaoj, apenas Aparecida nasceu antes de Jeremias. Em 1983, aos 30 anos de idade, Jeremias considerava-se "velho e acabado". Ele tinha fama de ser bravo (brabi) e, apesar de franzino, se metia a ser valente. Quase um mês após a missa-saravá registra-se uma das erupções de Jeremias.

Acordo com a voz ofegante de Jasmim, que fala com Anaoj: "Ele virou o capeta. Avançou pra cima de mim. Está quebrando tudo. Os ovos que eu comprei ele jogou tudo no chão. Pinguço! Eu largo aquela desgraça! Vontade de sumir...!" Decidida, Anaoj atravessa a valeta, deslocando-se em direção à tempestade. Os barulhos recrudescem (19/08/83).

A seguir, surge uma imagem de mãe: 
"Ai... ai... ai... ai... ai, meu Deus. Ai... ai". Os gemidos se prolongam. Aos poucos se afundam no corpo, tornando-se viscerais, e virando ânsia de vômito. "Mãe!" "Anaoj!" "Pressão baixa..."; "Tem que levar pro Pronto Socorro..."; "Anaoj, você quer ir pro Pronto Socorro?"

Sem alarde, Maria explica: "Toda vez que o Jeremias fica assim, a pressão dela baixa. É perigoso, não é? Pode morrer a qualquer hora".

"Ai... ai... ai."

Mister Zé sai para procurar um carro. "Você vai, Anaoj? Se eu chamar o carro e depois você não ir..." (19/08/83).

O sofrimento de Anaoj produz efeitos:

Maria olha para o alto. "Está vendo lá em cima? De vez em quando você vê a cabeça do Jeremias. Ele fica atrás da moita, espiando pra ver como é que está a mãe. Depois, se falar que a mãe ficou doente, ele vira uma onça. Avança pra cima de você".

Familiares se reúnem. Vizinhos perguntam sobre a saúde de Anaoj. Há um movimento de pessoas entrando e saindo do barraco de Anaoj e Mister Zé. Anaoj está de cama (19/08/83).

No início do mês, Anaoj havia aconselhado Jasmim, a sua nora, a dar "uma paulada" no Jeremias. Agora, porém, era a própria Anaoj que parecia ter levado a paulada. A mãe sentia no corpo as dores causadas por um filho. Essa imagem comovia. Causava impacto. Enquanto pessoas da vizinhança se reuniam em frente ao barraco de Anaoj, Jeremias observava.

Em novembro de 1983, há registros de novas brigas. Após receber uma conta no boteco, Jeremias ficou revoltado. Tomou pinga. Voltou tarde para casa. Brigou com a Jasmim. Bateu. Dessa vez até jogou uma cadeira contra Anaoj. No dia seguinte, tal como no espelho quebrado de Anaoj, em uma de suas faces mais cortantes, ou pungentes, lampeja a figura de uma senhora armada.

Na área do tanque, Anaoj limpa um frango para o almoço. Maria lava roupa. Ouve-se a voz de Anaoj: “Não aguento mais. Passei três noites sem dormir. Ele só pirraça eu. Eu nunca pirracei meu pai e minha mãe. Nunca! Ele sabe que eu sou doida, que eu não sou gente! Ou ele sai daqui ou eu furo ele! (Num gesto repentino e violento, Anaoj enfia a faca em um ser imaginário.) Furo aquela peste! Furo e dou risada! Ai, meu Deus do céu! Será que ele não sabe que eu sou mãe? Não sou cadela! Sabe o que eu vou fazer? Vou comprar um veneno pra eu tomar! Vocês vão ver!". 
Jeremias aparece na porta do barraco. "O que é mãe?"; "Não é nada não."; "O que é mãe?"; "O que é, o que é, o que é, o que é...". Os sons se repetindo ganham a intensidade de uma erupção. Furiosa Anaoj arremessa o frango! $(12 / 11 / 83)$.

O filho de Anaoj aqui aparece sob o signo de uma cadeira errante. Logo emerge a imagem de "mãe sofrida": "Não aguento mais. Passei três noites sem dormir". ${ }^{6}$ Dessa imagem irrompe outra: "Ele sabe que eu sou doida, que eu não sou gente! Ou ele sai daqui ou eu furo ele! Furo aquela peste! Furo e dou risada!". Em um único gesto - enfiando a faca que ela usa para limpar o frango - Anaoj produz uma imagem tensa. A mãe que prepara o alimento também é capaz de matar. Ambas as alternativas sinalizam uma condenação. Forçar Jeremias a sair do Jardim das Flores e da rede matrifocal que o protege não deixa de ser uma ameaça tão grande, talvez, quanto à que lampeja na lâmina de Anaoj. A raiva vira lamento: "Ai, meu Deus do céu! Será que ele não sabe que eu sou mãe?". O lamento se afunda virando raiva. Dessa vez, porém, a ameaça se apresenta através de uma imagem de mãe sofrida que acena com a sua própria morte.

O que seria de Jeremias sem a sua mãe? A resposta vem em forma de um gesto. O frango, que seria alimento, vira projétil. Nesse gesto se condensam as figuras de "mãe sofrida" e "doida de raiva". A cena tem o efeito de uma montagem, tal como a que se produz numa missa pontuada por tiros do Professor Pardal, ou nos cânticos de louvor acompanhados por um atabaque em estado de frenesi. Aqui, porém, a montagem se produz no corpo de uma única personagem e, até mesmo, em um único gesto.

Em março do ano seguinte, a briga entre Jasmim e Jeremias seria ainda mais tempestuosa. Com o cabo da faca ele bateu na cabeça de Jasmim. "Jorrou sangue". A própria Jasmim virou imagem de "mãe sofrida". Devido a um acidente no serviço de construção, que provocou a inflamação de uma de suas mãos, Jeremias não trabalhava desde janeiro. Mesmo com dois filhos pequenos, incluindo o neném, Jasmim foi catar algodão. A família começou a passar fome. Johnny, de 3 anos de idade, chutou de raiva as panelas vazias de sua mãe, até caírem na valeta. Jeremias bebia pinga. Jasmim se inervou. Irrompeu a briga. Jeremias ameaçou, "vou te matar!". Anaoj interveio, "então você vai ter que me matar primeiro!" (13/03/84). Jasmim refugiou-se com Johnny na casa de um tio materno, deixando o neném aos cuidados de Anaoj. Os amigos de Jeremias pararam de frequentar o seu barraco. A mão de Jeremias latejava. Estava infeccionada. Mesmo assim, enfaixando-a com um pano e cobrindo-a de plástico, Jeremias foi catar algodão. ${ }^{7}$ Virou "boia-fria". No final do dia ele trouxe da roça uma melancia para o seu filho, Johnny. 
Em 22 de março, uma semana após Jeremias haver virado "boia-fria", Jasmim voltou ao seu barraco e esposo. Anaoj devolveu o neném.

Um detalhe: dizia-se que no dia da briga Jasmim havia dado parte na polícia. Mas quando Jeremias tomou coragem de ir catar algodão, Anaoj lhe disse que a história não era verdadeira. Jeremias reagiu: "Eu não tenho medo de polícia! Eu queria que ela desse parte mesmo!" (14/03/84). Talvez o que tenha levado Jeremias a virar "boia-fria" tenha sido uma imagem de "mãe sofrida".

Anaoj e Daniel. Em 1983, Daniel tinha 18 anos de idade. Era o penúltimo dos filhos vivos. Solteiro, ele morava com os pais. Daniel "trampava". Quanto ao físico, ele era nessa época o mais forte da família. Aparentemente menos rebelde que Jeremias, sua melancolia talvez tenha sido mais profunda: "Sou pobre, e pobre tem que pegar no trampo até morrer, indo de trampo em trampo até o grito final" (20/05/83). "Estou acostumado a sofrer, e a dar cabeçada no mundo" (13/07/84).

Tal como outros "boias-frias", em épocas de safra da cana-de-açúcar, Daniel via-se em uma luta com os canaviais. Deparava-se no dia a dia com cana "brava", "enfezada", e "embramada". Não se sabia ao certo se era ele que cortava a cana, ou a cana de palha afiada que o cortava. Se era ele que derrubava a cana, ou a cana que o derrubava. Dos canaviais o seu corpo voltava moído. Virava-se bagaço.

Tal como a Mãe Coragem, cujo sustento vinha de uma guerra, o sustento de Anaoj vinha dos canaviais. As contas eram feitas na ponta do lápis, ou da língua. Exigia-se de Daniel uma entrega total:

Anaoj descobre que Daniel está fazendo Cr\$ 17 mil por semana. Dos dezessete, porém, ele só entregava dez para Anaoj. Ela reclama: "Mister Zé entrega tudo!". Maria apoia: "Zé do Mar também!". Adão, um dos irmãos mais velhos, dá razão para sua mãe. Anaoj comenta: "O Daniel compra duas, três garrafas de pinga pra tomar ele mais os colegas no serviço!" (25/07/83).

A cena não deixava de evocar uma imagem de Aparecida do Norte: "Você ouve o dia inteiro... plim, plim... o barulho do dinheiro caindo nos cofres do lado da santa" (27/05/83).

O comentário final de Anaoj, sobre as garrafas de pinga, serve para justificar a entrega do dinheiro à mãe. Mas ele também revela uma verdade de fundo: precisa-se de coragem para enfrentar um canavial.

Apesar da fama que Daniel tinha de "pegar no trampo", Anaoj se preocupava com as suas brigas de bar. 
Anaoj se lamenta: "Ai, meu Deus, não aguento mais. Desde que nós chegamos a Piracicaba é esse desgosto. Meus filhos desse jeito... Disgrama! Tinha que ir no bar!". "Daniel procura se explicar. "Mãe, eu, eu... tive que... Ele chamou de preto sujo!". Anaoj reage: "sujo?!" Daniel continua: "Fa... falei, 'eu trabalho. Não sou vagabundo que nem você!'". Anaoj explode: "Você devia é ter levado ele pra fora do bar e metido a mão na cara dele!" (04/07/83).

Primeiro, um lamento: a imagem de "mãe sofrida". A dor se transforma em raiva. De repente, uma explosão, em direção contrária à do lamento inicial.

As anotações finais da noite também são reveladoras:

Daniel volta cantarolando um dos hinos de missa. Naquela noite também se ouve no Jardim das Flores os hinos cantados por "crentes", em meio aos aleluias: "Aleluia! Glória a Deus!". Anaoj ironiza: "Sai até lágrima".

Antes de se deitar para dormir, Anaoj ri quando se lembra de uma outra vez em que alguém chamou Daniel de "preto sujo". Orgulhosa, ela diz: "Daniel voou em cima!" (04/07/83).

Aqui também se produz uma montagem. Daniel, que havia acabado de brigar e que levara dois "pitos" da mãe, primeiro por ter brigado e depois por não ter brigado até mais, "volta cantarolando um dos hinos de missa". Anaoj, que havia acabado de se lamentar, ri do choro dos "crentes" vizinhos. "Sai até lágrima". Antes havia se envergonhado dos filhos; agora se orgulha: "Daniel voou em cima!".

Os tiros que pontuavam o cotidiano do Jardim das Flores às vezes se tornavam expressivos. No final de agosto de 1983, Daniel disparou: "Vou fazer que nem o Professor Pardal. Vou comprar uma garrucha e tacar tiro pra cima!" (29/08/83).

\section{Primeira digressão: a revolta de Anaoj com o papel de mãe e mulher}

Existem papéis de vidro ou cerâmica? Olhando-se no espelho, a própria Anaoj às vezes parecia querer dar tiros, como se papéis de mãe e mulher pudessem virar estilhaços. Em maio de 1984, há claros sinais de rebeldia. "Bravo com Anaoj por ela não conseguir controlar os filhos, Mister Zé exclama: 'Os filhos todos chumbados!'. Anaoj retruca: 'Puxaram à sua mãe que vive chumbada!'" (14/05/84). 
Em junho, um vizinho, querendo que Mister Zé o acordasse na hora de sair para o trabalho, pergunta: "Anaoj, a que horas a senhora acorda o Mister Zé?". Anaoj responde: "Eu não acordo ele. Não sou relógio!". O vizinho insiste: "Mas a que horas a senhora levanta pra fazer a marmita dele?". Anaoj responde: "A hora que meus olhos estiverem se abrindo!" (Obs: Ela se levanta, geralmente, entre 4 h30 e 5h) (14/06/84). Os próprios programas de rádio incentivam nas madrugadas o papel a que Anaoj aqui se recusa: "Dona de casa, joga água na cara dele! Vamos trabalhar! Moleza! Dormindo a essa hora?!" (20/07/83).

As relações entre Anaoj e seus papéis de mãe e mulher entrariam em crise em 30 de junho de 1984, na festa organizada por universitários e moradores do Jardim das Flores. Dessa vez, ao invés de Anaoj controlar o seu filho Jeremias, os dois pareciam coreografar suas explosões numa festa-teatro em estado de embriaguez.

No dia seguinte, o clima estava carregado, sombrio. Mister Zé atacou: "Mulher que bebe pinga em festa é biscate!". Anaoj rebate: "Durante a semana eu sou sogra, mãe, e cozinheira. Mas durante a festa não sou nada disso! Quero beber pinga e dançar!" (01/07/84). Na segunda-feira, Anaoj parecia fazer penitência: "Triste, quieta, calada. Passou mal. Foi levada à farmácia. Tomou duas injeções" (02/07/84).

Quase dois meses após essa festa, os cadernos apresentam um registro marcante. Como estratégia para fazer um dinheiro extra, Anaoj começou a vender pinga no seu barraco. Inicialmente, ela havia pensado em montar uma quitanda. Porém, calculando os prováveis prejuízos de tal empreendimento, numa vizinhança em que a fome rondava e um código informal de reciprocidade se impunha, ela decidiu que seria melhor vender pinga. A pinga, que dissipava as forças de seus filhos, virou por alguns meses uma fonte de renda. Por causa de seu novo negócio, Anaoj veria seu nome envolvido numa briga que estourou num barraco vizinho.

\section{Segunda digressão: o caso de Zé Galinha}

Ouço os barulhos de uma briga entre Zé Galinha e a sua mulher, no barraco vizinho. Anaoj comenta: “Jorrou sangue!". Zé Galinha grita: “Você pensa que a polícia é mais homem do que eu?!".

A polícia chega. Zé Galinha reage: "Eu sou homem!". O policial desafia: "Por que você não bate em mim?! Olhe o rosto dessa criança, e de sua mulher que ainda está amamentando!".

Horas depois, ao lavar roupa, Maria levanta a sua voz em direção ao barraco de Zé Galinha: “Não gosto de gente que fala pelas costas! Por que não vem 
falar aqui?!". Maria estava com raiva. A vizinha havia dito que a culpa era de Anaoj por ter vendido pinga para Zé Galinha (25/08/84).

Trata-se de um fragmento insólito. Por detrás de uma imagem de "mãe sofrida" irrompe a polícia. Em um único gesto, atos contrastivos se sobrepõem numa montagem carregada de tensões: a agressão à mulher e o desafio à polícia — "Você pensa que a polícia é mais homem que eu?!". Paradoxalmente, a "covardia" de bater em uma mãe conjuga-se à "valentia" de enfrentar a polícia. Ao vender pinga, Anaoj se fragiliza. Configura-se um espantoso cotidiano: tal como uma Mãe Coragem, Anaoj fazia comércio com aquilo que estava matando os seus próprios filhos.

Anaoj e Moisés. Em 1983, Moisés era um menino de 10 anos de idade. Ia à escola de manhã e, à tarde, engraxava sapatos no centro da cidade. No registro a seguir um disparo do Professor Pardal acende a imaginação da mãe.

Ontem à noite, quando ouvi o tiro da garrucha, me deu uma tremura. Até a fome eu perdi. A Maria disse, "a mãe não quer comer mais". Eu não quis comer. Isso é da minha natureza. Eu sou revoltada. Comecei a pensar sobre o causo que o Zé do Mar contou do menino que foi levado pela chuva no Piracicamirim e da mãe que endoidou, com vontade de morrer. E o meu menino que vai pro centro trabalhar! Meu Deus, tanta coisa acontece nesse mundo! E se os marginais fizerem alguma coisa com meu menino? Eu, aqui, não sabendo de nada! O desespero e a preocupação vão acabar com o povo (10/06/83).

As palavras de Anaoj parecem entrar em relação de mimesis com o disparo da garrucha, despertando a nervura de um discurso amoroso e levando-o à beira de uma explosão. Nem por isso Anaoj deixava de empurrar o seu filho em direção ao mundo. A seguir, um reforço escolar:

Às 4h, Daniel sai para trabalhar. Às 6h30, ainda na cama, ouço a voz trêmula de Moisés tentando fazer frente aos estrondos de Anaoj: "Estou com frio". "Vai capeta! Vagabundo!". "Estou com frio". "Vai, senão arranco suas tripas pela boca!". "Não vou". "Você vai apanhar! Vou bater até ficar zonzo!".

Ouço barulhos na cozinha, seguidos pela batida da porta. "Não volto nunca mais!". "Não volta, senão te mato!".

Naquela noite, Mister Zé passaria um longo tempo segurando a cabeça de Moisés no colo, fazendo carinho, procurando piolhos (Nas escolas se fazem inspeção de cabeças para ver se as crianças têm piolhos) (16/06/83). 
Em suas relações com Moisés, a voz de Anaoj às vezes adquiria a qualidade de um tiro. "Arranco-seu-couro!". "Tem-que-amarrar-no-pau!". "Arranco-suas-tripas-pela-boca!". Perdiam-se vogais: "rntrapr-cá!" (entra pra cá). Palavras viram estrondos.

Com efeitos de choque, uma imagem faz o seu retorno. Uma mãe se recobre da persona aterrorizante da polícia: "Vou fazer com você que nem a polícia fez com o mineirinho, vou bater até...!" (14/07/84). No ano seguinte essa mesma imagem faria estremecer o corpo de Anaoj de horror:

Hoje Anaoj foi com um grupo de mulheres do bairro buscar cestas de alimentos da Dona Alzira, na Vila Rezende. Ela narra o que viu:

"Seis meninos cercaram uma mulher no ponto de ônibus. A mulher era rica, da família Dedini. Ia acontecer um roubo. Mas a polícia chegou antes. Pegaram um menino. Era um negrinho. Ergueram o menino no alto, e tacaram no chão. Chutaram de bota a sua barriga. Deram murros. Pa! Pa! Bateram a sua cabeça contra uma árvore. A orelha do menino começou a sangrar. O irmãozinho dele chegou perto. Gritaram: 'Você quer morrer?!'. Prenderam todos eles. Puseram no camburão. O menino saiu mancando, com o corpo todo quebrado. Ai que dó! Fiquei pensando, vai ver que é fome, não é? Era fome! O menino era magrinho. Parecia o Moisés. Quando vi a polícia batendo, fiquei mordida de raiva. Só de pensar que podia ser um menino meu. Uma mulher falou, 'a polícia não devia fazer aquilo com tantas mulheres olhando'. As mulheres chorando... Aquele branco troncudo ainda olhou feio pra nós!" (14/05/85).

Nesse relato mulheres e mães ocupam um espaço de mediação. A própria elite se recobre da persona de uma espécie de Nossa Senhora da Vila Rezende, num momento em que um grupo de mães do Jardim das Flores busca alimentos para os seus filhos. Um duplo dessa senhora aparece numa parada de ônibus.

A presença dos seis meninos produz uma revelação: a mediação dessa "Nossa Senhora" é insuficiente. "Era fome!". A imagem estranhamente familiar de um menino magrinho produz um efeito de interrupção: um choque. Os meninos evocavam imagens dos próprios filhos das mulheres do Jardim das Flores. Nesse momento, a Nossa Senhora da Vila Rezende revela um corpo assustador. Dissipando-se a aura, em seu lugar irrompe a imagem de um "branco troncudo". Assim se produz a inervação corporal das mães do Jardim das Flores. Sua raiva, dessa vez, dirige-se para o alto - tal como um tiro de garrucha do Professor Pardal.

O comentário de uma das mulheres - "a polícia não devia fazer aquilo com tantas mulheres olhando" — é particularmente insólito. O que dizer do adendo - "com tantas mulheres olhando"? Trairia a perturbação de quem vê 
algumas de suas relações inomináveis virem à luz? Revelaria, no lampejo da montagem carregada de tensões, uma espécie de cumplicidade subterrânea e espantosa entre a polícia e as próprias mães?

\section{Maria e Zé do Mar (filha e genro de Anaoj e Mister Zé)}

Em fins de novembro, enquanto fazia planos para desencostar seu cômodo do barraco de seus pais, Maria falou sobre o sofrimento de mulher:

Maria: "Mulher é o bicho mais sofrido da terra... e a mais vagabunda." Pagé: "A que mais trabalha."

Maria: "A que mais trabalha, mas a mais vagabunda, porque desfaz o que faz. Lava o copo, o copo torna a sujar. Lava roupa, a roupa torna a sujar. Lava a casa, a casa torna a sujar. Eu queria ser homem por modo de poder matar!" (28/11/83).

No momento em que Maria esboça uma imagem de "mulher sofrida", ela mesma se sacaneia: "Mulher é o bicho mais sofrido da terra... e a mais vagabunda". Ironizando ciclos de afazeres que se associam ao gênero feminino, um desejo aflora do fundo do corpo. Ao invés de elaborar seu esboço inicial, no qual se configuram os traços de uma "Nossa Senhora", o que emerge é uma vontade aparentemente estranha, com efeitos de espanto "Eu queria ser homem por modo de poder matar!". Haveria nos disparos do Professor Pardal a expressão de desejos suprimidos de uma mulher - a interrupção de um ciclo infernal?

Além do eterno retorno de afazeres cotidianos de Maria, outra espécie de ciclo infernal se evidencia ao longo dos cadernos de campo: os seus enfrentamentos com Zé do Mar. As relações ganham um cheiro de pólvora: "A Maria mais eu pusemos uma bombinha na dobra de sua calça. Mister Zé falou pra não fazer isso, porque podia quebrar a canela do rapaz. Mas era pra isso mesmo. Era pra ele parar de caminhar". (16/06/83). A própria sexta-feira santa adquire uma forma explosiva: "Maria e Zé do Mar discutem. Maria empurra. Zé do Mar reage: "Ué? Hoje pode bater?". Anaoj responde: "De tarde pode" (05/04/85). Uma lâmina lampeja: "Quando estou trabalhando, não vem não. Peão é solto! Essa faca aí, Maria!" (26/07/83). Em uma das brigas, quando Zé do Mar ameaçava bater em Maria, uma imagem familiar retornou: "Bate na polícia!" (17/09/84).

Porém, um dos registros leva as marcas de um momento extraordinário. Trata-se de um acontecimento único: Maria "avança" sobre a polícia em defesa de Zé do Mar. 
O clima está tenso. Em frente ao barraco de Anaoj vizinhos conversam. A polícia parou Zé do Mar, que voltava do "trampo", forçando-o a testemunhar a apreensão de maconha na casa de Mãozinha. Maria foi correndo em direção ao local. Orgulhosa da filha, Anaoj dizia: "A Maria ficou doida de raiva! Ela avançou no Luisão!" (investigador da polícia). Isso, para que Zé do Mar não fosse levado à delegacia.

Mãozinha foi algemado. "Coitado, as suas costas arrebentadas...". Quando a sua mãe se aproximou, o investigador a empurrou: "Sai, bruxa velha!" $(06 / 06 / 84)$

Foi esse provavelmente o melhor momento de Maria e Zé do Mar registrado nos cadernos. Dessa vez, os estrondos de Maria se dirigem contra a polícia. "Doida de raiva", ela defende Zé do Mar. A reação de Maria não deixa de evocar uma história carregada de tensões. Zé do Mar vinha do "trampo". Um detalhe: uma mãe é chamada de "bruxa velha".

\section{Anaoj e Mister Zé}

Nos termos de Leach (1983:129), como vimos no início, o poder que se atribui às Nossas Senhoras se associa à sua ação mediadora entre, de um lado, uma população de filhos e filhas nascidos nos substratos da sociedade e, de outro, remotas e poderosas figuras patriarcais. No espelho da família sagrada, no qual fulguram figuras do Divino, da Virgem Maria e seu filho, atenua-se uma imagem de José.

Os filhos de Anaoj tinham um pai: Mister Zé. Talvez a sua presença nos circuitos de família e vizinhança não fosse tão eletrizante quanto a de Anaoj. Mas para famílias que criam os seus filhos "com o suor dos braços", Mister Zé surge como uma figura exemplar.

Diversos trechos dos cadernos ressaltam a sua fama de trabalhador. "Mister Zé trabalha; 52 anos, e fazer o que ele faz! Ele leva um saco de cimento direto pro ombro! Muito moço não faz isso!" (24/05/83). "Anaoj conta que, hoje, o Mister Zé não foi trabalhar. 'Ele está doido pra ir trabalhar. Mas por causa de pressão baixa, ele precisou ir à Santa Casa'" (27/04/83). "Hoje é domingo, o 'Dia do Trabalhador'. Mister Zé foi colocar manilhas de 40 quilos no barro" (01/05/83).

A depender da disposição para "pegar no trampo", podia-se sempre contar com Mister Zé. O drama do Mister Zé era que ele não podia contar com o "trampo". Como dizia o compadre Antonio, "pobre vive como charuto em boca de bêbado". 
A despeito da admiração que as pessoas sentiam por Mister Zé, percebem-se, em alguns trechos dos cadernos, os sinais de dó e até mesmo desprezo: "O meu tio, coitado, aquele é trabalhador, aquele trabalha! Mas ganha pouco. E agora ele está ruim de saúde" (27/04/83). A manifestação mais explícita de desprezo pela figura de Mister Zé nos cadernos vem de Mestre Bimba, um rapaz que tinha fama de matar "bobos": "O Mister Zé é um coitado!" (10/06/83).

Alguns dos últimos fragmentos do período de 1983-85, referentes a Mister Zé, retomam, em séries sucessivas de lamentações, uma imagem de "coitado". "Olha o Zé chegando. Coitado, como está magro, o Zé! Ele está morrendo de trabalhar!" (08/02/85). "Nós não estamos aguentando mais, compadre Antonio. Eu estou pra endoidar. Coitado, o Zé está se acabando, morrendo aos pouquinhos de tanto trabalhar!" (17/05/85). A imagem de "coitado" ecoa num comentário de compadre Antônio sobre um bandido da vizinhança chamado Divino: "É, o Divino vai se dar mal. Ontem de noite ele tentou entrar no barraco do Mister Zé. O Mister Zé, coitado, está morrendo de tanto trabalhar, pra família dele não passar fome" (08/02/85).

As dores que Anaoj sentia por seus filhos, ela também sentia por Mister Zé. Mas essas cenas não deixam de suscitar imagens carregadas de tensões, envolvendo não apenas as relações entre Mister Zé e o Divino, mas também as suas relações com Anaoj. O trabalho que sustentava Anaoj e a sua família estava acabando com seu marido e seus filhos.

Os anos de trabalho produzem efeitos sobre o corpo de Mister Zé: "Se penicar os braços e as pernas, ele não sente. O corpo dele fica amortecido" (05/10/84). Em um dos registros observa-se uma competição insólita.

\footnotetext{
Ramiro, o sobrinho de Anaoj e Mister Zé, usa uma lima para tirar os calos das palmas de suas mãos. Olhando para as suas próprias mãos, e comparando-as com as do sobrinho, Mister Zé diz: "Você pode enfiar um alfinete na minha mão que eu não sinto. Você consegue fazer isso, Ramiro? Vamos ver quem consegue enfiar mais fundo?". O sobrinho ignora Mister Zé (20/11/84).
}

Talvez não haja nos cadernos imagem mais pungente do que esta para evocar o orgulho de Mister Zé por uma condição adquirida através do trabalho: a insensibilidade do seu corpo à dor. Aqui, a etimologia da palavra torna-se expressiva: tripalium, um instrumento de tortura medieval. O trabalho produz uma espécie de amortecimento. Anaoj também sentia no Jardim das Flores essa alienação do corpo: “Morar aqui está feito um sonho. Hoje amanheci com tudo doendo. Quando amanheci, não era meu corpo não" (17/08/83). 
Mas certas imagens suscitam um despertar. No dia em que Mister Zé "caiu na cana", virando "boia-fria", os cadernos registram os primeiros indícios de sua "valentia". Anaoj lembra-se com orgulho da vez em que, no bar do Risadinha, Mister Zé teria dito: "Vou matar aqui, agora. Vou bater pra amanhecer deitado!" (04/07/83). Dois dias depois, uma lembrança da roça arrepia um corpo amortecido pelo trabalho: "Mister Zé se anima, lembrando-se de uma cena: 'Hoje, a poliçaiada estava lá parada olhando todos nós - 50 homens, mulheres e crianças armados de facão! Os homens olhando, re, re'. Na hora de dormir, deitado na cama, Mister Zé conta de novo: 'a polícia no Morro Branco olhando a turma toda armada de facão, re, re'" (06/07/83).

Um registro revela uma lembrança luminosa. Mister Zé enfrenta um fazendeiro que matara muitos peões: "Eu trabalho a semana, a vida inteira pra você ficar bestando feito uma vagabunda!". Quando o fazendeiro do Norte de Minas Gerais ofereceu dinheiro, Mister Zé ainda teria dito: "Fica de gorjeta pra você! Isso é o meu suor pra você comer no caminho dos infernos!" (31/04/84). ${ }^{8}$

Num momento de perigo, em que Mister Zé se vê ameaçado de ficar sem o pagamento da semana, a imagem de homem "ruim" relampeia em narrativas de Anaoj: "Se o Zé não receber, ele vai fazer alguma coisa pra aquele homem. Zé é ruim!" (01/10/83). Em outra ocasião, depois de receber uma ninharia por 18 dias de trabalho sem contrato numa construção, Mister Zé esmoreceu. Anaoj enraiveceu. "Será que ele virou moleque agora?! Isso não é papel de homem! Falei pra ele: 'Zé, você vai lá e tira sangue se precisar! Você pode ir até preso, mas preso você não fica não!'" (04/02/84).

Em um dos registros, a própria Anaoj cai como um raio em frente a um boteco em defesa da honra de Mister Zé e da família: "Como é que você faz isso?! Deixou a cara do Zé no chão! O Zé derrama o suor dele pra nós não passarmos fome, e sempre pagamos as nossas dívidas! Mas pode deixar que nós não vamos mais comprar aqui não!". Quando o dono do boteco falou "mulher doida!", Anaoj retrucou: "Sou doida mesmo! Você está pensando que eu sou gente?! Rá! Não é com o suor do Zé e de meus filhos que você vai enricar!" (12/06/84).

Nessas anotações, Anaoj se apresenta em um de seus momentos mais redentores. Talvez seja de fato seu melhor momento nos cadernos enquanto "mãe e mulher". Justo aqui ela se revela como "mulher doida". "Você está pensando que eu sou gente?! Rá!". O "rá!" de Anaoj escapa como um disparo do fundo do seu corpo. Em um dos seus instantes mais expressivos como mãe e mulher, Anaoj revela-se como uma "mulher doida de raiva!". 


\section{Drama e montagem}

Retornam as questões: drama e montagem. Ilumina-se um percurso. De início, o modelo de drama social de Victor Turner parece ser propício para uma análise dos registros de cadernos de campo realizados no Jardim das Flores. Em dramas sociais, elementos estruturalmente arredios revitalizam processos estruturantes. Ruídos transformam-se em sons musicais tocando e recriando um corpo social. Mas o que dizer dos resíduos revoltos que permanecem às margens até mesmo dos fluxos poderosos de dramas sociais? Ou dos ruídos de paisagens sonoras - como um leve suspiro, um grito assombroso, ou um riso infernal - que, às vezes, escapam dos processos de organização do som? (cf. Dawsey 2009:352). A Virgem se cala, diz Kristeva. Creio que o princípio da montagem de Eisenstein possibilita uma espécie de audição. Os ruídos vêm das entranhas. E a voz da santa irrompe dos fundos, estrondosa, como um tiro de garrucha.

Em "O teatro em Aparecida: santa e lobisomem" (Dawsey 2006:146), escrevi:

Eis uma questão: o que a liturgia e o processo ritual separam em Aparecida, para fins de compor a imagem impassível da santa no espaço do sagrado, unese nas imagens carregadas de tensões no Jardim das Flores. Aquilo que estava reunido nos corpos dessas mulheres, tensionando-os, neles suscitando estados de inervação corporal, separava-se, em Aparecida, por meio de uma classificação binária operada pelo processo ritual, instituindo uma oposição entre sagrado e profano, catedral e parque de diversões, Aparecida e mulher-lobisomem.

Neste ensaio, procurei focar as inervações dos corpos no Jardim das Flores. Na literatura sobre grupos de baixa renda, desde as pesquisas sobre "cultura da pobreza", comportamentos "positivos" (reciprocidade, estabilidade etc.) tendem a se associar ao gênero feminino e à imagem de uma espécie de "mulher sofrida" (tal como a persona da Virgem Mãe do imaginário católico discutido por Kristeva). Os comportamentos "negativos" (violência, revolta, transgressão etc.) inclinam-se a se ligar ao gênero masculino (cf. Dawsey 1989:280-330). Nos termos do modelo de drama social de Turner, o gênero feminino associa-se à ação reparadora, e o masculino à ruptura e à crise. Creio, porém, que o princípio de montagem possibilita uma análise mais complexa das relações no Jardim das Flores. Neste local, imagens explosivas e "negativas" vinculadas ao gênero feminino, tais como a "mulher doida de raiva" ou a "filha de índia laçada no mato", também são mobilizadas e valorizadas por atores sociais. A oscilação veloz entre imagens de mulheres 
"sofridas" e "doidas de raiva", que se revela em registros de uma etnografia de casos desdobrados, diz algo sobre as tensões e os aspectos não resolvidos da vida social. Às vezes, "sofredoras" se transformam, repentinamente, em "doidas de raiva", e vice-versa. Gestos e imagens se fundem virando montagens. "Só tem vida o que é cheio de contradições". ${ }^{9}$

Nos registros de cadernos de campo, as tensões. Circuitos se iluminam. Anaoj e seus filhos. O primeiro deles, Jeremias. Três incidentes sucessivos, envolvendo uma mãe e um filho errante, violento. Lampeja a imagem poderosa de uma "mãe sofrida" que sente no corpo as dores provocadas por um filho em revolta. Percebe-se a comoção da vizinhança e o modo como as energias de um corpo social se avolumam em torno da figura de uma mãe. Em seguida, a oscilação veloz entre imagens da "mãe sofrida" e da "mulher doida" capaz de matar o próprio filho. As imagens se fundem em um único gesto. Finalmente, a repetição da primeira cena, com a nora, desta vez, como "mãe e mulher sofrida". O desdobramento é revelador: o filho (com a mão inflamada) vai catar algodão, virando "boia-fria". A mãe e sua nora se recobrem parcialmente da aura de uma Pietá.

O segundo filho, Daniel, revela-se como uma figura agonística, levando no corpo as dores do mundo do trabalho. No registro de cadernos de campo, o filho gaguejante procura explicar para uma mãe furiosa as circunstâncias de uma briga de bar. Na oscilação repentina de imagens, uma mãe que se lamenta por ter um filho briguento repreende-o por não ter brigado ainda mais. As imagens se fundem.

Primeira digressão. A revolta de Anaoj com o seu papel de mãe e mulher. E a contradição de uma mãe que, por um breve tempo, vende pinga para vizinhos, buscando sustento naquilo que ao mesmo tempo lhe causa revolta pela forma com que dissipa a força de seus filhos.

Segunda digressão. Paradoxalmente, em uma única imagem, a "covardia" de Zé Galinha de bater em uma "mãe sofrida" conjuga-se à "valentia" de enfrentar a polícia. A imagem de "poder do fraco" (cf. Turner 1969), que se associa à figura de "mãe sofrida", revela-se aqui de maneira insólita.

O terceiro filho, Moisés. Três registros sucessivos: a imagem de uma Pietá que sente no corpo as dores de um filho; a imagem de uma mãe transtornada que adquire a persona aterrorizante da polícia; e uma Pietá com raiva da polícia, com um adendo perturbador: indícios de cumplicidade entre polícia e Pietá.

O segundo conjunto de anotações de cadernos de campo tem a ver com as relações entre Maria e Zé do Mar, filha e genro de Anaoj e Mister Zé. No primeiro registro, o lamento de uma "mulher sofrida" interrompido por uma frase que irrompe de suas entranhas como o tiro de uma garrucha: 
"eu queria ser homem por modo de poder matar!". A seguir, uma série de enfrentamentos explosivos. Ameaças e contra-ameaças. Uma mulher com faca. E uma junção repentina: imagens de mulher e polícia. No último registro, o lampejo da imagem de uma "mulher doida de raiva". Desta vez, contra a polícia e em defesa do companheiro.

O terceiro conjunto: Anaoj e Mister Zé. Numa série de registros, uma imagem tensa: "trabalhador honrado"/"coitado morrendo de trabalhar". A seguir, nova série: "coitado"/homem "ruim" e valente "capaz de matar". Acompanhando essas séries, a imagem de Pietá, ou da "mulher sofrida", alternando com a da mulher em pé de guerra e que incita o companheiro a "tirar sangue". Por fim, a imagem explosiva da "mulher doida de raiva" enfrentando o dono de boteco: "Rá! Não é com o suor do Zé e de meus filhos que você vai enricar!".

Uma contradição de fundo, que evoca a figura da Mãe Coragem de Brecht, acompanha os registros: o sustento de mães e famílias vem de uma guerra sem fim, o mercado de trabalho que suga as forças de filhos e companheiros. "Mister Zé, coitado, está morrendo de trabalhar". A fórmula desta ladainha também foi usada por Anaoj em registros referentes a dois de seus filhos, Jeremias e Daniel, em momentos recorrentes de desemprego, quando, enfim, com muita resistência, e empurrados pela própria mãe, caíram nos fundões dos mundos do trabalho. Como efeito de estranhamento, o registro apresentado na primeira digressão é revelador: a revolta de Anaoj com o seu papel de mãe e mulher. Também são reveladores, ao longo dos cadernos de campo, os modos como mulheres subvertem seus papéis.

A Pietá sofre por seus filhos e companheiros. Trata-se de uma figura complexa. A imagem de "mãe e mulher sofrida" é poderosa. Ela comove um corpo social. E, em determinadas circunstâncias, ela mobiliza forças capazes de assimilar ou diluir até mesmo a revolta de filhos e companheiros errantes.

Em meio às tensões, a "mãe ou mulher sofrida" também se transforma em "mulher doida". Figura aterrorizante. Às vezes, ela ameaça fazer ruir as redes da vida que ela mesma teceu. Nesses momentos, qualquer aura de mãe se dissipa. Irrompe a imagem de mulher abjeta, perigosa e hedionda, capaz de subverter os fundamentos da ordem simbólica.

Os indícios de cumplicidade entre a imagem da Pietá e da polícia, que aparecem em alguns registros, podem ser perturbadores. A polícia (assim como, acredito, os meios de comunicação e as produções acadêmicas) às vezes mobiliza essa imagem, com efeitos sobre criaturas em revolta. A digressão sobre o caso de Zé Galinha é exemplar: "O policial desafia: 'Por que você não bate em mim?! Olhe o rosto dessa criança, e de sua mulher que ainda está amamentando!'". 
Apesar da aura associada à imagem de uma Pietá no Jardim das Flores, creio que aquilo sobre o que as mulheres mais gostavam de falar tinha a ver com as suas transformações repentinas em "mulheres doidas de raiva". Tais instantes, particularmente aqueles em que mães e mulheres irrompem com raiva contra as forças que colocam em risco a vida de filhos e companheiros, fazem parte de acervos de lembranças preciosas. Em momentos como esses, em que elas ameaçam tudo destruir, correndo riscos ainda maiores e revelando-se como mulheres perigosas, elas também refazem, em meio às inervações corporais, os laços amorosos que lhes dão os sentidos de viver.

Eis uma diferença em relação ao modelo de drama social de Victor Turner. O instante da ruptura coincide com o da cura. Em momentos explosivos detectase a liberação de energias retidas nos fundos de um corpo social. Lugar hediondo, sujo e liminar. Corpo de mãe-mulher. Nem eu, nem outro, nem nada. Ninguém. Mulher perigosa. Aparecida, aparição. Com espanto ela cura. E destrói.

\title{
A missa e o saravá
}

Afinidades entre Anaoj e o inventor de garruchas caseiras do saravá merecem atenção:

\begin{abstract}
Eu passo o dia assim sentado nessa cadeira... os números multiplicando, multiplicando na minha cabeça, minha cabeça fervilhando... Aí, eu levanto, vou lá fora e "pê!" — dou um tiro. Sento de novo na cadeira... os números multiplicando, multiplicando na minha cabeça, minha cabeça fervilhando... vou lá fora e "pê!" dou um tiro. Sento de novo na cadeira... até que, um dia, fico doido, vou lá fora e grito. Todo mundo acha que fiquei doido. Mas é aí que eu vou inventar alguma coisa! Por isso me chamam de Professor Pardal (17/06/83).
\end{abstract}

Anaoj também passava horas e horas com a cabeça fervilhando. Tais períodos de "aquecimento" precediam as suas irrupções. Em seu corpo de mãe e mulher, virando imagem carregada de tensões, suscitava-se a inervação de um corpo social.

No espelho mágico da missa rezada pelo Padre Ângelo, as pessoas do "buraco dos capetas" transfiguram-se em personagens de um drama de proporções cósmicas. ${ }^{10}$ Mas os estrondos que irrompem do barraco do saravá, com tiros de garrucha e sons de atabaque, fazem estremecer o espelho, que se parte ao meio. Num espelho partido, com efeitos de montagem, produzemse imagens de senhoras do Jardim das Flores. Uma Nossa Senhora assim se revela na justaposição da missa à saudação ruidosa do "saravá!". "Ave 
Maria!". Com estrondos ela salva. Assim como imagens não resolvidas, com efeitos de despertar, emergiam em revoada os tiros do Professor Pardal.

Também há afinidades entre o barraco do saravá e os palcos sobre os quais Brecht ensaiava um teatro épico e seus "efeitos de estranhamento" (Verfremdungseffekt). Se a missa do Padre Ângelo apresentava-se como uma espécie de "teatro do maravilhoso", os disparos do Professor Pardal produziam um abalo. "Mais do que uma semiologia", diz Roland Barthes (1987:194), "o que deveríamos reter de Brecht seria uma sismologia", um abalo da "logosfera". Talvez seja isso, também, o que devemos reter dos tiros de garrucha. Em corpos de mães e mulheres do Jardim das Flores, o "buraco dos capetas", ressoam os ruídos e os estrondos de linhagens sobrepostas, como placas geológicas que se friccionam em meio aos movimentos sísmicos. Das camadas mais fundas de um corpo social, nos domínios de Mater Dei, irrompe uma matéria incandescente. Imagens de mães primordiais: "nêgas de senzala" e "índias laçadas no mato". Étrangers à nous-mêmes (Kristeva 1988). Em tais circunstâncias a etnografia adquire — sob o signo de Benjamin, Kristeva e Artaud — as qualidades de uma espécie de "história noturna" de Nossa Senhora do Jardim das Flores. ${ }^{11}$

Relampeiam imagens de estratos suprimidos, com inversões de sinais, energizando um corpo social. No extraordinário cotidiano do Jardim das Flores, com estrondos, imagens de mães e mulheres suscitam a inervação de corpos adormecidos e amortecidos. Circuitos se acendem? Em meio a curtos-circuitos, incendeiam. Nesses registros, o que seria um curto-circuito senão uma iluminação profana - um clarão de luz negra que irrompe do fundo do "buraco dos capetas"? ${ }^{12}$

Anaoj tomava um susto a cada tiro do Professor Pardal. Até que ponto ela se assustava consigo mesma? Assim se diz em Grande sertão: veredas (Rosa 1988:11): "Deus mesmo, quando vier, que venha armado!". No espelho mágico e quebrado do Jardim das Flores não me surpreenderia se ele viesse no corpo de uma senhora com rosto de Diadorim.

Recebido em 02 de junho de 2011

Aprovado em 28 de março de 2012

John Dawsey é professor titular do Departamento de Antropologia e coordenador do Núcleo de Antropologia, Performance e Drama (Napedra) do Programa de Pós-Graduação em Antropologia Social (PPGAS) da Universidade de São Paulo. E-mail: <johndaws@usp.br> 


\section{Notas}

* Agradeço à Fundação de Amparo à Pesquisa do Estado de São Paulo (Fapesp) e ao Conselho Nacional de Desenvolvimento Científico e Tecnológico (CNPq) por apoios recebidos para o desenvolvimento desta pesquisa.

${ }^{1}$ Os nomes próprios que constam do texto podem ser considerados como ficções literárias do pesquisador. Esta observação também é válida para o nome "Jardim das Flores". O termo "buraco dos capetas", assim como o nome "João Branco", do pesquisador, não deixam de ser ficções reais, nascidas da poesia dos moradores.

${ }^{2}$ Morei em um cômodo feito por Mister Zé, ao lado do barraco ocupado por ele e Anaoj, de abril a dezembro de 1983. Registros de cadernos de campo foram feitos de 6 de março de 1983 a 28 de maio de 1985. As primeiras conversas com Anaoj, anotadas em cadernos, aconteceram em 1 de junho de 1978, em época anterior ao período de pesquisa, quando a conheci. Após um período de ausência do Brasil, de dezembro de 1979 a julho de 1982, retomei os contatos com Anaoj e Mister Zé com o objetivo de realizar uma pesquisa de tese de doutorado sobre relações de trabalho dos boias-frias. Falei com eles sobre as possibilidades de alugar um barraco no Jardim das Flores. Mas eles sugeriram que eu morasse com eles, em cômodo feito por Mister Zé. Na primeira semana em que eu estava morando no cômodo caiado, um menino de 10 anos de idade escreveu em sua fachada: "esta casa quem mora é João, mas quem fez foi Mister Zé". Ao todo, foram 354 registros em cadernos de campo, com datas diferentes.

${ }^{3}$ A metáfora do "espelho mágico" aparece em vários escritos de Victor Turner (Cf. Turner 1987:22). No espelho mágico de uma experiência liminar, a sociedade pode ver-se a si mesma a partir de múltiplos ângulos, experimentando, num estado de subjuntividade, as formas alteradas do ser.

${ }^{4}$ Sugiro a noção de "baixo corpo social" como forma de evocar a ideia de baixo corporal (Bakhtin 1993) no registro de um corpo social. E sugiro a ideia de inconsciente sonoro como o equivalente auditivo da noção benjaminiana de inconsciente óptico (Cf. Benjamin 1985b). A expressão "história noturna" se inspira no título traduzido de um dos livros de Carlo Ginzburg (1991).

${ }^{5}$ Publicado originalmente como "L'Herethique de l'amour" (Kristeva 1977).

${ }^{6} \mathrm{O}$ número três pode estar funcionando aqui como uma fórmula da tradição oral, de origem bíblica, evocativa da morte e da ressurreição de Cristo. Anaoj conta que quando ela recebeu uma carta com pano preto no Paraná, sinalizando que seu pai havia morrido, ela e Aparecida, sua filha mais velha, ficaram três dias de cama. Depois de três dias, conforme a tradição, Jesus ressurgiu dos mortos.

${ }^{7}$ A cata do algodão era vista como serviço de mulher e criança. Isto por privilegiar a agilidade das mãos e a baixa estatura. Em algumas propriedades do interior do Estado de São Paulo, o plantio da cana intercalava-se com o plantio do algodão. 
${ }^{8}$ A frase talvez esteja evocando, com ironia, uma passagem bíblica citada em liturgias de santas ceias: "Isto é o meu corpo, que é dado por vós; fazei isto em memória de mim. Por semelhante modo, depois de haver ceado, tomou também o cálice..." (1 Co 11.23-25).

${ }^{9}$ A frase vem de Brecht (apud Bornheim 1992:272).

${ }^{10}$ Cf. nota 4 .

${ }^{11}$ Cf. nota 5. A expressão "história noturna" se inspira em título traduzido de um dos livros de Carlo Ginzburg (1991).

${ }^{12}$ A ideia de "iluminação profana" sugere um duplo estranhamento, em relação ao cotidiano e ao extraordinário também (Cf. Benjamin 1985a:35).

\section{Referências bibliográficas}

ARTAUD, Antonin. 1987. O teatro e o seu duplo. São Paulo: Max Limonad.

BAKHTIN, Mikhail. 1993. A cultura popular na Idade Média e no Renascimento. São Paulo: Hucitec/ Brasília: Ed. da UnB.

BARTHES, Roland. 1987. "Brecht e o discurso: contribuição para o estudo da discursividade". In: O rumor da língua. Lisboa: Edições 70. pp. 193-200.

BENJAMIN, Walter. 1985a. "O surrealismo". In: Obras escolhidas: magia e técnica, arte e política. São Paulo: Brasiliense. pp. 21-35. 1985b. "A obra de arte na era da reprodutibilidade técnica". In: Obras escolhidas: magia e técnica, arte e política. São Paulo: Brasiliense. pp. 165-196.

BORNHEIM, Gerd. 1992. Brecht: a estética do teatro. São Paulo: Graal.

BRECHT, Bertolt. 1991. "Mãe coragem e seus filhos". In: Teatro completo 6 . Rio de Janeiro: Paz e Terra. pp. 171-266.
DAWSEY, John C. 1989. Vila Vitória: the emergence of proletarian culture. Ann Arbor, Michigan: UMI. .1999. De que riem os "boias-frias"? Walter Benjamin e o teatro épico de Brecht em carrocerias de caminhões. Tese de Livre-Docência em Antropologia Social, Programa de Pós-Graduação em Antropologia Social, Faculdade de Filosofia, Letras e Ciências Humanas da Universidade de São Paulo.

.2005. "O teatro dos 'boias-frias': repensando a antropologia da performance". Horizontes Antropológicos, 24:15-34. .2006. "O teatro em Aparecida: a santa e o lobisomem". Mana. Estudos de Antropologia Social, 12(1):135-150. .2009. "Por uma antropologia benjaminiana: repensando paradigmas do teatro dramático". Mana. Estudos de Antropologia Social, 15(2):349-376. DOUGLAS, Mary. 1976. Pureza e perigo. São Paulo: Perspectiva. 
EISENSTEIN, Sergei. 1990a. A forma do filme. Rio de Janeiro: Jorge Zahar. - 1990b. O sentido do filme. Rio de Janeiro: Zahar.

GEERTZ, Clifford. 1983. "Blurred genres: the refiguration of social thought". In: Local knowledge. New York: Basic Books. pp. 19-35.

GINZBURG, Carlo. 1991. História noturna: decifrando o Sabá. São Paulo: Companhia das Letras.

KRISTEVA, Julia. 1977. "Herethique de l'amour". Tel Quel, 74:30-49. - 1980. Pouvoirs de l'horreur. Paris: Editions du Seuil. - 1988. Étrangers à nous-mêmes. Paris: Fayard.

. 2002a. "Stabat mater". In: The portable Kristeva. Ed. Kelly Oliver. New York: Columbia University Press. pp. 310-332.

-2002b. The portable Kristeva. Ed. Kelly Oliver. New York: Columbia University Press.

LEACH, Edmund. 1983. "Nascimento virgem". In: Edmund Leach. São Paulo: Ática. pp. 116-138.

MARCUS, George E. 1994. "The modernist sensibility in recent ethnographic writing and the cinematic metaphor of montage". In: L. Taylor (org.), Visualizing theory. New York and London: Routledge. pp. 37-53.

ROSA, João Guimarães. 1988. Grande Sertão: Veredas. Rio de Janeiro: Nova Fronteira.

TAUSSIG, Michael. 1986. Shamanism, colonialism, and the wild man: a study in terror and healing. Chicago/ London: The University of Chicago Press.

TURNER, Victor. 1969. "Liminality and communitas". In: The ritual process: structure and anti-structure. Ithaca, New York: Cornell University Press. pp. 94-130.
1974. "Hidalgo: history as social drama". In: Dramas, fields and metaphors: symbolic action in human society. Ithaca and London: Cornell University Press. pp. 98-155. . 1982. "Introduction". In: From ritual to theatre: the human seriousness of play. New York: PAJ Publications. pp. 7-19. . 1987. "Images and reflections: ritual, drama, carnival, film and spectacle in cultural performance". In: The anthropology of performance. New York: PAJ Publications. pp. 21-32. - 1996. Schism and continuity in an african society. Washington, D.C.: Berg. 


\section{Resumo}

Neste artigo, ao discutir o modo como se configuram imagens de Nossa Senhora e de mães e mulheres no Jardim das Flores (ou "buraco dos capetas"), na periferia de uma cidade do interior paulista, pretende-se explorar a especificidade de estéticas dramáticas. A seguir, ainda mais do que a estética do drama social, associada à obra de Victor Turner, o princípio da montagem, que se inspira no cinema de Sergei Eisenstein, ilumina registros de cadernos de campo. E com Eisenstein - Julia Kristeva, Walter Benjamin, Michael Taussig, e Antonin Artaud. A quem se dispuser a fazer uma audição dessas mulheres, sugiro cautela. Pois em nossos ouvidos talvez ressoem os tiros de uma garrucha.

Palavras-chave: Montagem, Drama, Gênero, Mãe, Nossa Senhora

\section{Abstract}

While discussing images of Our Lady and of the mothers and women of the Garden of Flowers (or "Devils' Hole"), a peripheral district of a city in the interior of São Paulo state, this paper intends to explore the specificity of dramatic aesthetics. Rather than depend upon the aesthetics of social drama, as discussed in the works of Victor Turner, the present paper deals with a concept of montage that is inspired by the cinema of Sergei Eisenstein in order to illuminate a selection of field notes... and, along with Eisenstein, Julia Kristeva, Walter Benjamin, Michael Taussig and Antonin Artaud. Wit regards to those readers interested in hearing what these women may have to say, caution is suggested, for the words of these women may ring in our ears as the sounds of musket shots

Key words: Montage, Drama, Gender, Mother, Our Lady 